\title{
COMPARISON OF LEARNING STRATEGIES IN FACE-TO-FACE AND ONLINE COURSES ON SEXUALLY TRANSMITTED DISEASES ${ }^{1}$
}

\author{
Viviane Rolim de Holanda², Ana Karina Bezerra Pinheiro ${ }^{3}$
}

${ }^{1}$ Paper extracted from the dissertation - Educational hypermedia to teach sexually transmissible conditions: construction,
validation and assessment, presented to the Graduate Nursing Program at Universidade Federal do Ceará (UFC), in 2014.
${ }^{2}$ Ph.D. in Nursing. Faculty, Nursing Group at Universidade Federal de Pernambuco. Vitória de Santo Antão, Pernambuco,
Brazil. E-mail: vivi_rolim@yahoo.com.br
${ }^{3}$ Ph.D. in Nursing. Faculty, Graduate Nursing Program at UFC. Fortaleza, Ceará, Brazil. E-mail: anakarinaufc@hotmail.com

ABSTRACT: The goal of this study was to compare undergraduate nursing students' learning after using educational hypermedia with the traditional approach in lectures on the subject of sexually transmitted diseases. This is a quasi-experimental study conducted at two federal universities in the Northeast from June till August 2013. A total of 58 students participated, who were divided into two similar groups (control and intervention). Values of $p<0.05$ were considered statistically significant. In the post-test, the statistical analysis did not show significant differences in learning performance between the groups $(\mathrm{p}=0.151)$. The intervention group answered the largest number of questions correctly $(54.46 \%)$. It is concluded that educational hypermedia represents a complementary tool for face-to-face teaching in undergraduate nursing courses.

DESCRIPTORS: Education in nursing. Learning. Educational technology. Hypermedia. Sexually transmitted diseases.

\section{COMPARAÇÃO DE ESTRATÉGIAS DE APRENDIZAGEM NAS MODALIDADES PRESENCIAL E ON-LINE SOBRE DOENÇAS SEXUALMENTE TRANSMISSÍVEIS}

RESUMO: Objetivou-se comparar a aprendizagem de acadêmicos de enfermagem, após a utilização de hipermídia educativa, com a abordagem tradicional em aula expositiva sobre o assunto-foco das doenças sexualmente transmissíveis. Estudo quase experimental realizado em duas universidades federais da Região Nordeste brasileira, durante o período de junho a agosto de 2013. Participaram 58 estudantes divididos em dois grupos semelhantes (controle e intervenção). Considerou-se nível de significância de 5\% nos testes estatísticos realizados. No pós-teste, a análise estatística não indicou diferenças significativas no rendimento acadêmico entre os grupos $(\mathrm{p}=0,151)$. Houve maior acerto de questões no grupo intervenção $(54,46 \%)$. Conclui-se que a hipermídia educativa representa uma ferramenta complementar ao ensino presencial na graduação em enfermagem.

DESCRITORES: Educação em enfermagem. Aprendizagem. Tecnologia educacional. Hipermídia. Doenças sexualmente transmissíveis.

\section{COMPARACIÓN DE ESTRATEGIAS DE APRENDIZAJE EN CLASES PRESENCIALES Y ONLINE SOBRE ENFERMEDADES SEXUALMENTE TRANSMISIBLES}

RESUMEN: El objetivo de este estudio fue comparar el aprendizaje de estudiantes de enfermería después del uso de sistemas hipermedia educativos con el enfoque tradicional en clases expositivas sobre el tema-foco de las enfermedades de sexualmente transmisibles. Se trata de un estudio cuasi-experimental realizado en dos universidades federales en la región noreste, de junio a agosto de 2013. Participaron 58 estudiantes que fueron divididos en dos grupos similares (control e intervención). Valores de $p<0,05$ fueron considerados estadísticamente significativos. En el post-test, el análisis estadístico no indicó diferencias significativas de aprendizaje entre los grupos $(\mathrm{p}=0,151)$. Hubo un número mayor de respuestas correctas en el grupo intervención $(54,46 \%)$. Se concluye que sistemas hipermedia educativos representan una herramienta complementaria en la enseñanza presencial de estudios de grado en enfermería.

DESCRIPTORES: Educación en enfermería. Aprendizaje. Tecnología educativa. Hipermedia. Enfermedades sexualmente transmisibles. 


\section{INTRODUCTION}

Significant changes in the relationship between teaching and learning processes have happened as a result of the development of information and communication technologies (ICT). There was a large increase in the number of courses, both in the classroom and in distance learning, mediated by digital technologies. ${ }^{1}$

In education, ICTs are transforming the ways we learn and teach. The use of computers and the Internet become part of teaching and are adopted in the traditional approach as well as in distance learning. ${ }^{2}$

It is noticed that the information technologies provide for high interaction levels among participants, breaking with the idea of space and time. Thus, in online environments, what was distant can become close. The dimension of time and space is set up according to the needs, interests and wishes of learners, expanding the possibilities of education. Therefore, it is appropriate to adopt the term online education for the process mediated by ICTs in virtual learning environments. ${ }^{3-4}$

In Brazil, due to the growing demand for specific skills and knowledge, the virtual object has been used as a teaching strategy to facilitate learning in nursing care. ${ }^{5}$

The National Curricular Guidelines for the undergraduate program in nursing support the educational initiatives using ICTs to provide a new way of learning and teaching. Higher education institutions can create teaching units, integrated to the curriculum and focusing on self-learning, using digital technologies with educational objectives, provided that they do not exceed $20 \%$ of the total course hours. ${ }^{6-7}$

Online education is expanding and thereby affecting the learning process, especially in higher education. The nursing education follows this trend, allowing students to seek knowledge and skills digitally and exchange them with others in virtual spaces. In this sense, it is believed that ICTs create stimuli and challenges for teacher practice and nursing education. ${ }^{8}$ Consequently, the need to use ICT in nursing is increasingly evident, as a tool to encourage the development of teaching; research is necessary, however, to clarify the evidence and the impact of these technologies in learning. ${ }^{2,9}$

Advances in ICTs offer constant innovations for teachers to develop teaching strategies that facilitate the teaching-learning process. An integrative review showed the increasing use of technology in various disciplines of nursing higher education. The integration of digital objects was not evidenced as an educational learning strategy on Sexually Transmitted Diseases (STD) though. ${ }^{10}$

In primary health care, the nurses perform care, organizational and educational functions for the control of STDs. They need systemization to ensure quality care, development of educational programs for prevention, treatment guidance, counseling, offering of tests and condoms, approach of sexual partners and case notifications.

In this context, learning how to use the syndromic approach of STDs during the undergraduate course becomes important for nursing education, since the failure of care in the community can contribute to perpetuate the transmission chain of sexual infections. Therefore, this study is justified by the possibility to improve the gaps observed in the teaching of STDs in nursing undergraduate programs, using a validated digital teaching resource ${ }^{4}$ to facilitate the students' learning.

Based on the considerations presented, this study is relevant to awaken the nursing students to the knowledge required for the management of STDs in primary health care, contributing to the improvement of education in nursing through the application of research on pedagogical models and the current assessment practices.

Based on the need to recognize the importance of the use of digital technologies in the learning of nursing students and the difficulties students reported in lectures on sexual and reproductive health, this study aimed to compare the learning of nursing students after the use of educational hypermedia with the traditional approach in lectures on the STDs.

\section{METHOD}

Quasi-experimental study conducted at two federal universities in the Northeast of Brazil, during the period from June to August 2013. For data collection, two groups of students were constituted (control group and intervention group).

The selection of participants was carried out by convenience. The inclusion criteria for the control group were: be a student of the undergraduate course in nursing and be enrolled in the nursing discipline Nursing in the Care Process in Sexual and Reproductive Health of the Faculty of Pharmacy, Dentistry and Nursing at the Universidade Federal de Pernambuco. 
The intervention group included undergraduate students enrolled in nursing and in the nursing discipline Gynecology and Obstetrics of the Universidade Federal de Pernambuco / Vitória Academic Center. It is noteworthy that the intervention and control groups did not receive prior information on the theme sexual infections in the disciplines mentioned. In both groups, students younger than 18 years and/or who failed those disciplines were excluded. The control group had access to the dialogued lecture, with a load of 4 hours, taught by teachers with experience in the subject, in the traditional classroom, using multimedia projection with Microsoft PowerPoint ${ }^{\circledR}$ slides as a teaching resource.

The lecture followed the same content planned for the modules in the virtual environment. The content of the course programme addressed the management of STDs in primary health care, the syndromic approach and nursing care for the main STDs (genital ulcers, urethral discharge, cervicitis and vulvovaginitis, pelvic pain and genital warts/infection by human papillomavirus - HPV).

To evaluate the profile of the students, an adapted instrument ${ }^{11-12}$ was used and a validated questionnaire ${ }^{4}$ was applied to evaluate the content at the beginning (pre-test) and at the end of the lessons (post-test).

The intervention group had access to a hypermedia on STDs in the virtual environment SOLAR. The hypermedia was named "Nursing and sexually transmitted diseases" and validated for technical and content aspects. ${ }^{4}$ Similarly, the procedures of the first group were followed: characterization of the students' profile, application of pre-test before teaching practice, and post-test immediately after online educational intervention.

In the intervention group, two face-to-face meetings were carried out in the computer laboratory, lasting one hour each. In the first face-to-face meeting, the teaching strategy, the application of questionnaires for the characterization of the students and the pre-test, the registration of students and the setting of hypermedia in the virtual environment were presented. In the second faceto-face meeting, the post-test and the questionnaire to evaluate the hypermedia were applied.

Students had free access to hypermedia within a one-week period, the time elapsed between the face-to-face meetings. During this period, the student could connect to the virtual learning platform SOLAR from any computer by internet access, at their own home or at the university, according to their interest and time availability. At the end, tutoring was provided for the sake of follow-up on the questions pertinent to the subject and the activities of online modules.

Data were analyzed using Statistical Package for Social Sciences (SPSS), version 20.0. Statistical significance was set at $p<0.05$. The homogeneity between the group proportions was tested using Fisher's Exact Test. To characterize the students, Fisher's Exact Test and the Maximum Likelihood Independence Test were used.

The Wilcoxon Test (paired samples) was used to compare the mean outcome of the scores for each group in the evaluation stages (pre-test and post-test) and the Mann-Whitney Test was used to compare means between groups (control and intervention).

The study received approval from the Institutional Review Board of the Federal University of the State of Ceará, according to protocol 191 533/2013. All participating students signed the Informed Consent Form.

\section{RESULTS}

Fifty-eight students from the undergraduate nursing program participated, $30(51.7 \%)$ in the control group (traditional approach) and 28 $(48.3 \%)$ in the intervention group (virtual environment). In the control group, four students refused to participate in the post-test. Statistical tests denoted that the groups were similar (Fisher Test, $\mathrm{p}$-value $=1.000$ ) regarding the aspects related to sociodemographic variables, digital streaming, access to technology and prior knowledge on STDs.

Most nursing students were female (93.1\%) and single $(87.9 \%)$. The average age was 22.7 years old, with a standard deviation of 2.3 years old. With regard to prior knowledge, the participating students reported having limited knowledge on STDs $(62.06 \%)$ and the syndromic approach $(55.17 \%)$. Few mentioned having gained experience through courses $(8.62 \%)$ or trainings in STD care services $(24.13 \%)$.

Regarding the digital fluency, most students accessed the Internet daily $(89.7 \%)$ to perform academic work, to connect to social networks and to exchange emails. All participating students had computers at homes, used electronic mail (e-mail), had internet access and prior computer knowledge. 
It is noteworthy that the media most used to keep them informed and updated were Internet (79.3\%) and television (15.5\%), respectively. The primary site of internet access was their own residence $(96.6 \%)$ (Table 1$)$.

Table 1 - Digital fluency and access to technology of nursing undergraduate students participating in the research. Fortaleza-CE, 2014

\begin{tabular}{|c|c|c|c|c|c|}
\hline \multirow{2}{*}{ Variables } & \multicolumn{2}{|c|}{ Intervention group } & \multicolumn{2}{|c|}{ Control group } & \multirow{2}{*}{$\mathrm{p}^{*}$ - Value } \\
\hline & f & $\%$ & $\mathrm{f}$ & $\%$ & \\
\hline Prior computer knowledge & 28 & 100.0 & 30 & 100.0 & \\
\hline Attended computer course & 15 & 53.6 & 12 & 40.0 & 0.430 \\
\hline Navigability on the Internet & 28 & 100.0 & 30 & 100.0 & \\
\hline Use of chat (chat rooms) & 16 & 57.1 & 18 & 60.0 & 1.000 \\
\hline Use of electronic mail (e-mail) & 28 & 100.0 & 30 & 100.0 & \\
\hline Participation in courses or disciplines online & 4 & 14.3 & 13 & 43.3 & $0.021 \dagger$ \\
\hline Computer availability at home & 28 & 100.0 & 30 & 100.0 & \\
\hline Access to the Internet & 28 & 100.0 & 30 & 100.0 & \\
\hline \multicolumn{6}{|l|}{ Type of access to the Internet } \\
\hline Dial-up internet connection - phone line & 4 & 14.3 & 1 & 3.3 & 0.187 \\
\hline Fast internet access - broad-band access & 20 & 71.4 & 28 & 93.3 & $0.038 \dagger$ \\
\hline Radio & 4 & 14.3 & 1 & 3.3 & 0.187 \\
\hline \multicolumn{6}{|l|}{ Frequency of access to the Internet } \\
\hline Daily & 24 & 85.7 & 28 & 93.3 & 0.415 \\
\hline 3-5 times per week & 3 & 10.7 & 2 & 6.7 & 0.665 \\
\hline Sporadically & 1 & 3.6 & - & - & 0.483 \\
\hline Hardly ever & - & - & - & - & \\
\hline \multicolumn{6}{|l|}{ Most frequent place of access to the Internet } \\
\hline Home & 27 & 96.4 & 29 & 96.7 & 0.128 \\
\hline University & 1 & 3.6 & 1 & 3.3 & 1.000 \\
\hline Friends' house/relatives' house & - & - & - & - & \\
\hline Lan house & - & - & - & - & \\
\hline Work & - & - & - & - & \\
\hline \multicolumn{6}{|l|}{ Most used means of communication } \\
\hline Jornal & 1 & 3.6 & 1 & 3.3 & 1.000 \\
\hline Magazine & 1 & 3.6 & - & - & 0.483 \\
\hline TV & 4 & 14.3 & 5 & 16.7 & 1.000 \\
\hline Radio & - & - & - & - & \\
\hline Internet & 22 & 78.6 & 24 & 80.0 & $0.016 \dagger$ \\
\hline \multicolumn{6}{|l|}{ Main use of the Internet } \\
\hline Academic papers & 13 & 46.4 & 11 & 36.7 & 0.595 \\
\hline Communication via e-mail & 4 & 14.3 & 6 & 20.0 & 0.732 \\
\hline Social networks and chat & 8 & 28.6 & 9 & 30.0 & 1.000 \\
\hline Courses and classes & 1 & 3.6 & 2 & 6.7 & 1.000 \\
\hline Entertaining & 2 & 7.1 & 2 & 6.7 & 1.000 \\
\hline
\end{tabular}

* Fisher's Exact Test; †Statistically significant.

To evaluate the learning contents, the number of correct answers on the pre-test and post-test were compared in the two groups (control and intervention). In the pre-test, the difference in the number of correct answers between the groups was statistically significant $(p=0.049)$. The average of correct answers in the control group was 13.57 $(\mathrm{SD}=2.012)$, and the average of the intervention group was $12.21(\mathrm{SD}=2.833)$.
In the post-test, the statistical analysis did not show significant differences in the academic performance between the intervention and control groups ( $p=0.151)$. It is important to note, however, that both groups had significantly higher results in the post-test, which reflects learning both in the traditional teaching approach $(p=0.000)$ and in the virtual environment $(p=0.000)$. 
It is observed that the intervention group had a lower academic performance in the pre-test and achieved a higher average number of correct answers in the post-test compared to the control group. In the post-test, the mean score increased by $4.20(30.95 \%)$ questions in the control group and $6.65(54.46 \%)$ questions in the intervention group. The result is shown in table 2 .

Table 2 - Comparison of learning before and after the traditional method of teaching and the virtual environment. Fortaleza-CE, 2014

\begin{tabular}{|c|c|c|c|}
\hline Academic performance & (number of correct answers) & Control group & Intervention group \\
\hline \multirow{6}{*}{ Pre-test } & $\mathrm{n}$ & 30 & 28 \\
\hline & $\%$ & 100.0 & 100.0 \\
\hline & Mode & 14 & 11 \\
\hline & Median & 13.50 & 12.00 \\
\hline & Arithmetic mean & 13.57 & 12.21 \\
\hline & Standard deviation & 2.012 & 2.833 \\
\hline \multirow[t]{2}{*}{ P-value* (between groups) } & $0.049 \ddagger$ & & \\
\hline & $\mathrm{n}$ & 26 & 28 \\
\hline \multirow{5}{*}{ Post-test } & $\%$ & 86.7 & 100.0 \\
\hline & Mode & 18 & 23 \\
\hline & Median & 18 & 20.0 \\
\hline & Arithmetic mean & 17.77 & 18.86 \\
\hline & Standard deviation & 2.286 & 4.034 \\
\hline & P-value "(between groups) & & \\
\hline \multicolumn{2}{|c|}{ P-value ${ }^{\dagger}$ (between Pre-test and Post-test) } & $0.000^{\ddagger}$ & $0.000^{\ddagger}$ \\
\hline
\end{tabular}

* Mann-Whitney Test; † Wilcoxon Test; łStatistically significant.

\section{DISCUSSION}

By observing the characteristics of the urdergraduate students in relation to other studies involving nursing students, similarity in profiles was identified, as there was a predominance of female and single students, with a mean age of 22.7 years old, using computers and having access to the Internet. ${ }^{12-17}$

Researchers who evaluated educational computer software from the perspective of the nursing undergraduate students linked to five Brazilian public universities also found a similar profile of the participants. This is explained by the high frequency of computer use in their residences, which determines people's routine, in this case the students', within the current conjuncture of having a computer for family or individual use. ${ }^{14}$ Currently, undergraduate nursing students, as the vast majority of students have shown great familiarity with the Internet and its tools, use them frequently. ${ }^{18}$

Research conducted on digital fluency and use of virtual environments has shown that undergraduate students in nursing from the University of São Paulo presented knowledge, skill and expressive interest in these environments during their academic studies. They were considered digi- tally fluents since they were able to find, evaluate and use digital information effectively, efficiently and ethically. ${ }^{15}$

Undergraduate nursing students participating in research on digital learning stated that computer use helped them in the organization of study time. The fact that the students are young and have prior computer knowledge collaborated so that there was no difficulty in the use of the virtual environment. ${ }^{19}$

The profile of the successful virtual student was aged around 25 years old, with some higher education in progress, disciplined and motivated, critical thinking, clearly expressing their ideas and knowing how to self-manage their study schedule. ${ }^{20}$ On the other hand, it is emphasized that the success of the virtual student is directly related to the tool used, the way in which teachers lead their classes, and especially the motivation to attend the course and the availability of the resources needed for the desired interactivity. ${ }^{15}$

In online teaching strategies, it is important to know the digital fluency of students, since the lack of computer knowledge can affect their ability to communicate effectively with the teacher/tutor, making their participation in online activities difficult. ${ }^{21}$ Thus, the knowledge of the students' 
characteristics creates conditions for the teacher to act on personal difficulties in a personalized fashion, so that, at the end of the process, all students are able to achieve the learning objectives defined in the classroom/course, despite individual differences. $^{22}$

The undergraduate nursing students in this study reported that they had limited knowledge about STDs. This finding corroborates the results of other investigations. ${ }^{23-27}$

The present research aimed at identifying the level of knowledge among undergraduate nursing students about STD-related factors and identified the need for greater investments in education of young people to promote health and prevention of STDs. ${ }^{23}$

This study revealed that there is a lack of knowledge on STDs among young undergraduates. It was observed that the most known STDs among undergraduate students were HIV/AIDS $(93 \%)$, followed by gonorrhea $(80 \%)$, syphilis $(71 \%)$ and herpes $(64 \%)$. There was deficient specific knowledge on donovanosis and trichomoniasis. Condom was the best known method of prevention among young people surveyed. ${ }^{24}$ Another study also appointed lack of knowledge of undergraduate students in the health care area about preventive aspects of STDs. ${ }^{25}$

An analysis on the knowledge of the nurses in the Family Health Strategy of the city of Fortaleza, in the State of Ceará, regarding the management of syphilis during pregnancy revealed low knowledge on actions involving prevention and control in pregnant women. It further appointed that most nurses did not have appropriate knowledge about the types of treponemal and nontreponemal tests and treatment in the secondary phase. ${ }^{26}$ Accordingly, an epidemiological analysis in the State of Ceará on congenital syphilis indicated an increase in cases over the last ten years and lack of actions focused on its control. It indicated the need for health professionals, especially nurses, to properly use the flow of actions recommended by the Ministry of Health for prevention and early diagnosis. ${ }^{27}$

In the current health context, it is important that undergraduate nursing students learn how to properly use the syndromic approach and STD prevention strategies. In this context, the development of efficient teaching and learning strategies is interesting as an auxiliary teaching resource, combining theory and practice with simulated cases and presentation of structured information, contextualized images and videos that can stimulate learning.

The results presented in this study demonstrate that online learning is as effective a strategy as the face-to-face approach (traditional approach) and can be used as a complementary teaching resource in nursing education. The academic performance observed in the students from the intervention group supports other reports described in the literature, which investigated the educational approach mediated by the computer and the Internet. The results of a study provided evidence that undergraduate nursing students are able to manage their own learning and to build personal knowledge after using computer simulation..$^{28}$ Other researchers have developed and evaluated a multimedia application on mobile platforms (cell phones) for teaching measurement of central venous pressure (CVP). They showed that, in nursing education, the available technology could uncover new ways of learning, offering students the opportunity to improve the relationship between theory and practice..$^{29}$

In addition, a study that aimed to describe the experience of a virtual learning environment opted to merge online activities with face-to-face meetings, discussions, guidance and combined building of educational activities. The results presented show that the resources of the virtual environment helped in teaching strategy, creating problem-solving situations to enhance the individual and collective discussion of the themes. ${ }^{30}$

A systematic review on the contributions of the application of virtual objects to the learning process has revealed that these contribute significantly to the increase of knowledge, establishing a promising approach to health and nursing education. The virtual objects increase the students' knowledge, impacting the learning media used in online courses and in satisfaction with the usefulness, quality, presentation and appropriateness of the contents. ${ }^{31}$ Another study developed a virtual environment for continuing nursing education on cardiopulmonary resuscitation in neonatology. The virtual environment was evaluated positively and appointed as a useful strategy for learning, skills development and vocational training of nurses. ${ }^{32}$ Similarly, a research that created an educational software and compared the acquisition of knowledge about the indwelling urinary catheterization procedure before and after applying the software demonstrated its significant efficacy in teaching after its implementation, and 
showed to be very useful as a teaching tool in the process of learning. ${ }^{17}$

A quasi-experimental before-and-after study was carried out to assess the results of the implementation of a virtual object in the pain assessment learning of undergraduate nursing students. It showed a significant difference in learning after the intervention $(p=0.03)$, with an increase in the mean post-test score. The educational tool was highlighted regarding its flexibility of access (time/ place), freedom to decide the best way of learning and the resemblance to reality. The weekly average web access of students for educational purposes and the use of resources mediated by ICT indicate the students' familiarity with such resources, which can provide learning experiences. ${ }^{33}$

The research analysis that compares the knowledge of nursing students who used a virtual environment with participants in the traditional approach on contraceptive methods indicated the absence of statistically significant differences between groups (control and intervention), appointing equivalent results in student learning in both teaching modalities. It was recognized, however, that the use of new teaching technologies in nursing could favor the acquisition of knowledge and represent an auxiliary mode to complement classroom teaching. ${ }^{12}$

One researcher, comparing the performance of dental undergraduate students who used hypermedia and the traditional method, revealed that the hypermedia technology and use of the Internet, when used alone, without any face-to-face lesson, was similar to the conventional teaching strategy centered on the teacher. The application of hypermedia combined with the traditional method was considered as a complementary strategy or learning facilitator, with better results in the academic performance of students. ${ }^{34}$

A study carried out with nursing students from Cairo (Egypt) also recommended the use of mixed methods of learning, with the combination of the strengths of face-to-face approach and e-learning modalities. It pointed out that it is essential during higher education to include a variety of teaching methods to reach the educational goals, as they provide different levels of learning for knowledge building purposes. ${ }^{21}$

Another study described the experience in the discipline of Parasitology and Medical Mycology in the Medicine program at the Federal University of Health Sciences in Porto Alegre (UFCSPA), considering the use of the environment Moodle to provide the materials used in face-to-face lessons and the use of forum and chat resources. When comparing the scores of students who participated in the chats with those who did not participate, a significant increase was observed in the scores of students who participated in the activities in chats with positive assessments of learning. ${ }^{35}$

It is noticed that the adoption of ICTs causes changes in the traditional educational paradigm by promoting new forms of teaching and learning, inducing new behaviors in teachers and students, new forms of relationships, new ways of thinking and producing knowledge. ${ }^{32}$ The use of technology as a tool in the teaching/learning, however, occurs in a timid way in the face-to-face teaching of nursing courses at higher education institutions. On the other hand, there is an agreement that the restricted use of digital materials in nursing alone does not guarantee more significant learning when compared to the face-to-face approach activities. ${ }^{19}$ Preliminarily, coherent educational planning is necessary, in view of the intended educational goals when applying technological resources.

\section{CONCLUSION}

Information and communication technologies have been intensified in recent years, pushing more and more changes in various knowledge areas, and particularly in education. New online learning methods should be part of face-to-face education. Inserting content and digital materials in undergraduate nursing courses constitutes a great challenge for educators though.

By comparing the application of the traditional teaching method and the virtual environment, the results did not indicate significant differences between the means of content evaluation between the control and intervention groups. An increase was shown, however, in the mean post-test score in the intervention group, which presented the highest number of correct answers.

Based on the above, the obtained findings may have several implications for nursing, especially for the teaching practice. When compared to the traditional teaching approach, hypermedia promote active learning and encourage the teaching and learning process in a collaborative fashion, valuing self-learning and respect for each student's study rhythm. Thus, it is understood that the educational hypermedia constitutes a teaching tool to support classroom teaching in nursing undergraduate programs. 
In a world immersed in technology, with more and more content available in various media, higher education needs to move forward with flexible and hybrid proposals, which integration of physical and virtual spaces, permeated by active methods.

It is noteworthy that the main limitation of this study refers to the size of the undergraduate nursing student sample, which can be subject to biases that may interfere in the interpretation of the results. A larger and more diversified sample would be necessary, including representatives from universities all over the country, to assess the outcome of digital tools in the learning process of undergraduate nursing students.

Nursing teachers should encourage the development of new teaching materials, specifically on sexual and reproductive health, as there is a lack of publications on interactive and validated teaching materials that may facilitate the teachinglearning process. There is governmental interest in controlling and preventing STDs in primary health care. It is expected, therefore, that these materials improve human resource training and clinical nursing practice.

From this perspective, the online teaching strategy in undergraduate nursing program revealed the need for further studies in this knowledge area to enhance the potential of media learning objects in the students' learning process.

\section{REFERENCES}

1. Fruet FSO, Bastos FP. Interação mediada por computador: hipermídia educacional nas atividades de estudo a distância. Conjectura. 2010 Mai-Ago; 15(2):81-98.

2. Bastable SB. O enfermeiro como educador: princípios de ensino-aprendizagem para a prática de enfermagem. Porto Alegre (RS): Artmed; 2010.

3. Dias DC, Cassiani SHB. Educação de enfermagem sem distâncias: uma ruptura espaço/temporal. Rev Esc Enferm USP. 2004 Dez; 38(4):467-74.

4. Holanda VR. Hipermídia educacional para o ensino das doenças sexualmente transmissíveis: construção, validação e avaliação [tese]. Fortaleza (CE): Universidade Federal do Ceará, Programa de Pós-Graduação em Enfermagem; 2014.

5. Góes FSN. Desenvolvimento e avaliação de objeto virtual de aprendizagem interativo sobre o raciocínio diagnóstico em enfermagem aplicado ao recémnascido [tese]. Ribeirão Preto (SP): Universidade de São Paulo, Programa de Pós-Graduação em Enfermagem; 2010.
6. Brasil. Resolução n. 3, de 7 de novembro de 2001. Institui diretrizes curriculares nacionais do curso de graduação em Enfermagem. Diário Oficial da República Federativa do Brasil, 9 Nov 2001. Seção 1.

7. Brasil. Portaria n. 4059, de 10 dez de dezembro de 2004. Introdução na organização pedagógica e curricular dos cursos superiores reconhecidos a oferta de disciplinas integrantes do currículo que utilizem modalidade semipresencial, com base no art. 81 da Lei $n^{\circ}$ 9.394, de 1996. Diário Oficial da República Federativa do Brasil, 13 Dez 2004. Seção 1.

8. Holanda VR, Pinheiro AKB, Pagliuca LMF. Aprendizagem na educação online: análise de conceito. Rev Bras Enferm. 2013 Mai-Jun; 66(3):40611.

9. Aguiar RV, Cassiani SHB. Desenvolvimento e avaliação de ambiente virtual de aprendizagem em curso profissionalizante de enfermagem. Rev LatinoAm Enferm. 2007 Dez; 15(6):1086-91.

10. Holanda VR, Pinheiro AKB, Fernandes AFC, Holanda ER, Souza MA, Santos SMJ. Análise da produção científica nacional sobre a utilização de tecnologias digitais na formação de enfermeiros. Rev Eletr Enf [online]. 2013 Out-Dez [acesso 2014 Out 04]; 15(4):1068-77. Disponível em: http:/ / www. fen.ufg.br/fen_revista/v15/n4/pdf/v15n4a26.pdf

11. Aguiar RV. Desenvolvimento, implementação e avaliação de ambiente virtual de aprendizagem em um curso profissionalizante de enfermagem [tese]. Ribeirão Preto (SP): Universidade de São Paulo, Programa de Pós- Graduação em Enfermagem; 2006.

12. Aquino PS. Tecnologia educativa no ensino de enfermagem em contracepção [tese]. Fortaleza (CE): Universidade Federal do Ceará, Programa de PósGraduação em Enfermagem; 2010.

13. Leite KNS, Santos SR, Andrade SSC, Zaccara AAL, Costa TF. A internet e sua influência no processo ensino-aprendizagem de estudantes de enfermagem. Rev Enferm UERJ. 2013 Out-Dez; 21(4):464-70.

14. Fonseca LMM, Aredes ND, Leite AM, Santos CB, Lima RAG, Scochi CGS. Avaliação de uma tecnologia educacional para a avaliação clínica de recém-nascidos prematuros. Rev Latino-Am Enferm [online]. 2013 Jan-Fev [acesso 2014 Jul 20]; 21(1): [08 telas]. Disponível em: http:/ / www.scielo.br/pdf/ rlae/v21n1/v21n1a11.pdf

15. Costa PB, Prado C, Oliveira LFT, Peres HHC, Massarollo MCKB, Fernandes MFP, et al. Digital fluency and the use of virtual environments: the characterization of nursing students. Rev Esc Enferm USP. 2011 Dez; 45(esp):1589-94.

16. Silva APSS, Pedro ENR, Cogo ALP. Chat educacional em enfermagem: possibilidades de interação no meio virtual. Rev Esc Enferm USP. 2001 Out; 45(5):1213-20. 
17. Lopes ACC, Ferreira AA, Fernandes JAL, Morita ABPS, Poveda VB, Souza AJS. Construção e avaliação de software educacional sobre cateterismo urinário de demora. Rev Esc Enferm USP. 2011 Mar; 45(1):215-22.

18. Alavarce DC, Pierin AMG. Elaboração de uma hipermídia educacional para o ensino do procedimento de medida da pressão arterial. Rev Esc Enferm USP. 2011 Ago; 45(4):939-44.

19. Tanaka RY, Catalan VM, Zemiack J, Pedro ENR, Cogo ALP, Silveira DT. Objeto educacional digital: avaliação da ferramenta para prática de ensino em enfermagem. Acta Paul Enferm. 2010 Out; 23(5):603-7.

20. Palloff RM, Pratt K. O aluno virtual: um guia para trabalhar com estudantes online. Porto Alegre (RS): Artmed; 2004.

21. Abdelaziz M, Kamel SS, Karam O, Abdelrahman A. Evaluation of e-learning program versus traditional lecture instruction for undergraduate nursing students in a faculty of nursing. Teach Learn Nurs. 2011 Abr; 6(2):50-8.

22. Silva EC, Corradi-Websterz CM. Competência social para interagir em ambientes virtuais de aprendizagem. Invest Educ Enferm. 2011 Mar; 29(1):97-102.

23. Panobianco MS, Lima ADF, Oliveira ISB, Gozzo TO. O conhecimento sobre o HPV entre adolescentes estudantes de graduação em enfermagem. Texto Contexto Enferm [online]. 2013 Jan-Mar [acesso 2014 Jul 20]; 22(1):201-7. Disponível em: http://www. scielo.br/pdf/tce/v22n1/pt_24.pdf

24. Fontes KALF, Alves TS, Oliveira JCS, Costa IG. Conhecimento de jovens universitários sobre doenças sexualmente transmissíveis. Rev Matogrossense Enferm. 2010 Jun-Jul; 1(1):63-77.

25. Falcão Júnior JSP, Freitas LV, Lopes EM, Rabelo STO, Pinheiro AKB, Ximenes LB. Conhecimentos de universitários da área da saúde sobre contracepção e prevenção de doenças sexualmente transmissíveis. Enfermería Global. 2009 Fev; 8(1):1-12.

26. Andrade RFV, Lima NBG, Araújo MAL, Silva DMA, Melo SP. Conhecimento dos enfermeiros acerca do manejo da gestante com exame de VDRL reagente. J Bras Doenças Sex Transm. 2011; 23(4):188-93.

27. Costa CC, Freitas LV, Sousa DMN, Oliveira LL, Chagas ACMA, Lopes MVO, Damasceno AKC. Sífilis congênita no Ceará: análise epidemiológica de uma década. Rev Esc Enferm USP. 2013 Fev; 47(1):152-9.

28. Virtanen HM, Leino-Kilpi H, Leinonen KB, Puukka PM, Wontso J, Salantera S. Nursing student control over using a computer simulation program about empowering discourse. Comput Inform, Nurs. 2013 Oct; 31(10):512-22.

29. Galvão ECF, Puschel VAA. Aplicativo multimídia em plataforma móvel para o ensino da mensuração da pressão venosa central. Rev Esc Enferm USP. 2012; 46(esp):107-15.

30. Silva LMG, Gutierrez MGR, Domenico EBL. Ambiente virtual de aprendizagem na educação continuada em enfermagem. Acta Paul Enferm. 2013; 23(5):701-4.

31. Alvarez AG, Dal Sasso GTM. Objetos virtuais de aprendizagem: contribuições para o processo de aprendizagem em saúde e enfermagem. Acta Paul Enferm. 2011; 24(5):707-11.

32. Rodrigues RCV, Peres HHC. Desenvolvimento de ambiente virtual de aprendizagem em enfermagem sobre ressuscitação cardiorrespiratória em neonatologia. Rev Esc Enferm USP. 2013 Fev; 47(1):235-41.

33. Alvarez AG, Dal Sasso GTM. Aplicação de objeto virtual de aprendizagem, para avaliação simulada de dor aguda, em estudantes de enfermagem. Rev Latino Am Enferm. 2011 Mar-Abr; 19(2):229-37.

34. Lemos EM. Ensino-aprendizagem em endodontia: aplicação da hipermídia e o uso da internet como facilitadores do processo [tese]. São Paulo (SP): Universidade de São Paulo, Programa de PósGraduação em Odontologia; 2010.

35. Mezzari A. O uso da aprendizagem baseada em problemas $(\mathrm{ABP})$ como reforço ao ensino presencial utilizando o ambiente de aprendizagem Moodle. Rev Bras Educ Med. 2011 Mar; 35(1):114-21. 